ISMC 2021

$16^{\text {th }}$ International Strategic Management Conference

\title{
DOES EVA INFLUENCE THE LEVEL OF EARNINGS MANAGEMENT PRACTICES?
}

\author{
Anna Siekelova (a)* \\ *Corresponding author \\ (a) University of Zilina, Faculty of Operation and Economics of Transport and Communications, Univerzitna 1, \\ 01026 Zilina, Slovakia, anna.siekelova@fpedas.uniza.sk
}

\begin{abstract}
The profit is the resulting effect of the enterprise's business activity and, at the same time, often the measure of whether the company is successful or not. The contribution deals with the issue of earnings management. It can be stated that the issue of earnings management is a modern phenomenon in recent years. The aim of the contribution is testing hypothesis about the existence of statistically significant relationship between the economic value added indicator and the level of earnings management practices within database. Data was obtained from the Amadeus database. The database contains 15,295 small and medium-sized companies operating in V4 countries. The research was focused on companies operating in NACE Rev. 2 main section: I. Accommodation and food services activities. There are several method of the earnings management measurement. The modified Jones model was chosen within the contribution. According to many authors, the model has sufficient explanatory power and it is used worldwide in many studies. The one-way ANOVA was used to test the hypothesis. Based on the results, there is a statistically significant relationship between EVA indicator and the level of the earnings management practices. Companies with higher value of EVA indicator use the earnings management practices to decrease reported profit. On the other hand, companies with lower value of EVA indicator use the earnings management practices to increase reported profit.
\end{abstract}

2357-1330 @ 2021 Published by European Publisher.

Keywords: Earnings, earnings management, economic value added, EVA, modified jones model 


\section{Introduction}

Academic scientists have been dealing with the issue of earnings management practices (hereafter "EM") since at least the 1960s. In recent years, the issue of earnings management has become known not only to the academic community but also to the general public. By using the earnings management practices within the company, the level of the reported financial indicators can be questionable. The aim of the contribution is testing hypothesis about the existence of statistically significant relationship between the economic value added indicator and the level of earnings management practices within database.

\section{Literature Review}

The issue of the earnings management is reviewed mainly by foreign authors who have been dealing with its types, motives or models for its detection.

At the beginning, authors were dealt with the impact of the earnings management practices mainly on capital market. They tested the existence of the relationship between the level of the earnings management and stock prices. It is also known as the era of the mechanistic hypothesis (Ball, 1972; Kaplan \& Roll 1972; Rath \& Sun, 2008). Authors stated that stock prices are influenced mainly by reported financial indicators and investors do not focused on the accounting policy of the company. Contrary to the mechanistic hypothesis, the efficient market hypothesis was based on the assumption that stock prices are influenced by all publicly known information (not only financial reports) and the impact of the choice of accounting policy on profit is one of this information (Fama, 1970; Mayer-Sommer, 1979).

Schipper (1989) defined earnings management as a purposeful intervention in the external financial reporting process, with the intent of obtaining some private gain. This definition is focused on the external reporting function. It does not include managerial accounting reports or activities that influence or change GAAP. Based on the definition, earnings management is a part of the external disclosure process in various forms.

There are several methods to estimate earnings management practices within firms. Beneish (2001) compares three definitions of earnings management, as well as three methods of measuring earnings management within firms, namely aggregate accruals, specific accruals and discontinuities in earnings distribution. Discusses evidence relating to the reasons for income-increasing earnings management, income-decreasing earnings management and specific contexts, e.g., financial institutions with regulatory constraints. Concludes that, although the evidence is limited, managers are more likely to manipulate income up rather than down; and identifies some opportunities for further research.

It can be seen that the earnings management has an important impact on the reliable of the reported financial indicators. The chosen accounting policy can influence the information within income statements, as well as balance sheets. It has impact on the stock prices, capital market, creditors, banks, investors or financial institutions (Connolly-Barker et al., 2020; Khan et al., 2020). 
The aim of the contribution is testing hypothesis about the existence of statistically significant relationship between the economic value added indicator and the level of earnings management practices within database.

\section{Research Method}

\subsection{Economic Value Added Estimation}

Data were obtained from the Amadeus database. The following steps show the used search strategy.

- All active companies from 2015 to 2019;

- Countries: Slovakia, Czech Republic, Hungary, Poland;

- Total assets min. 2,000,000 EUR;

- Operating revenues min. 100,000 EUR;

- Companies operating in Accommodation and food services activities;

- Exclusion of companies with no recent financial data for calculation;

- Outliers detection.

As can be seen, seven search rules were used. The database contains 15,295 small and medium-sized companies operating in V4 countries. The research was focused on companies operating in NACE Rev. 2 main section: I. Accommodation and food services activities. In the final step, outliers were detected. There are several methods for outliers detection. Based on the Interquartile range method by Turkey outlier can be defined as a value below $Q_{1}-1.5(I Q R)$ or above $Q_{3}+1.5(I Q R)$, where $Q_{3}$ means the third quartile and $Q_{1}$ means the upper quartile. Values indicated as the outlier were excluded from the database.

The aim of the contribution is to test the hypotheses if there exists a statistically significant relationship between the value of EVA and the level of the earnings management practices used in the companies. For EVA calculation, it is necessary to calculate the net operating profit after tax (NOPAT), the net operating assets (NOA), as well as the weighted average costs of capital (WACC). One of the most difficult steps in calculating the EVA indicator is to adjust the financial statements, mainly the balance sheet and profit and loss, to reflect its economic reality. Stern Stewart \& Co recommends making 164 adjustments, of which only a few are in practice realized. The recommended adjustments are a trade secret of this company. Net operating assets represent the invested capital that a company needs to operate. The transformation of assets into economic data requires the following steps:

- total assets need to be adjusted for assets that are not related to the company's operating assets,

- the assets must be reduced by the amount of interest-bearing foreign capital,

- unusual items have to be excluded,

- transformation accounting assets into actual assets.

NOPAT is calculated as follow:

- add interest paid to the profit or loss,

- exclude unusual items

- take into account the effect of changes in equity, 
- assess the operational nature of financial investments and current assets (if they are not related to the core business, they should be excluded),

- convert modified taxes (taxes paid on net operating profit after tax) (Williams et al, 2020; Whittle et al, 2019).

The weighted average cost of capital includes both shareholder-owned capital (equity) and debt. Each capital category is weighted proportionally. The weighted average cost of capital can be calculated as the sum of the costs of each component of capital multiplied by their relative weight. This relationship expresses the following formula.

Where:

$$
W A C C=\frac{D}{C} * r_{d} *(1-t)+\frac{E}{C} * r_{e}
$$

$D \quad$ Debt;

C Capital;

$r_{d} \quad$ Cost of Debt;

$t \quad$ Taxes;

E Equity;

$r_{e} \quad$ Cost of Equity.

The cost of debt is determined primarily for explicitly interest-bearing capital. It can be stated, the cost of debt are calculated as an average effective interest rate paid by the company from various forms of foreign capital. If we do not have enough information to determine the effective interest rate and the possible issue of bonds is not publicly traded, then it is necessary to calculate the cost of debt as Damodaran recommended (Virglerova et al., 2020; Vrbka et al., 2019). The following formula can be used.

$$
r_{d}=r_{f}+r_{p}
$$

Where:

$r_{d} \quad$ Cost of Debt;

$r_{f} \quad$ Risk-Free Rate of Return Derived from The Yield of Government Bonds;

$r_{p} \quad$ The Risk Premium of a Particular Company (determined either on the basis of the company's rating or the amount of the interest coverage ratio; it can be found online by using professor Damodaran website).

The cost of equity was calculated by using the CAPM (Capital Asset Pricing Model). CAPM takes into account the riskiness of an investment relative to the market. The model is less exact due to the estimates made in the calculation (because it uses historical information). The following formula can be used.

Where:

$$
r_{e}=r_{f}+\beta\left(r_{m}-r_{f}\right)
$$

$r_{f} \quad$ Risk-Free Rate of Return Derived from The Yield of Government Bonds;

$\beta \quad$ Beta of Asset;

$r_{m} \quad$ Expected Market Return. 
The measure of systematic risk (the volatility) of the asset relative to the market. Beta can be found online by using professor Damodaran website.

\subsection{Earnings Management Estimation}

Accruals are defined as a difference between net income and cash flows. The sum of total accruals contains a non-discretionary component or non-discretionary accruals (NDA), as well as a discretionary component or discretionary accruals (DA). DA corresponds to adjustments made to the cash flow, selected by managers focused on their interests in terms of earnings. NDA corresponds to adjustments made to the cash flow, resulting from the application of accounting standards in a rational manner and considering the evolving economic conditions of the company (Kliestik et al, 2020). There are two approaches to total accruals calculation. The following formula is used for total accruals calculation. It is also known as the balance sheet approach (Svabova et al, 2018, Svabova et al, 2020).

$$
T A=\triangle C A-\triangle C L-\triangle C a s h+\triangle S T D-D e p
$$

Where:

$T A \quad$ the sum of total accruals;

$\triangle C A \quad$ the change in current assets;

$\triangle C L \quad$ the change in current liabilities;

$\Delta$ Cash the change in cash and cash equivalents;

$\triangle S T D$ the change in the current maturities of long-term debt and other short-term debt included in current liabilities;

Dep depreciation and amortization expenses.

To earnings management practices calculation, the modified Jones model was used. There are also some studies that prove that the modified Jones model is the most powerful technique to indicate EM initiatives compared to the others (e.g. industry model, Healy DeAngelo model or standard Jones model) (Ayu et al., 2020; Grofcikova, 2020; Vagner et al., 2021). Based on the modified Jones model, discretionary accruals estimation is calculated using the following formulas.

$$
\begin{gathered}
\frac{T A_{i t}}{A_{\mathrm{it}-1}}=\alpha_{0} \frac{1}{A_{\mathrm{it}-1}}+\alpha_{1} \frac{\Delta R E V_{i t}-\Delta R E C_{i t}}{A_{i t-1}}+\alpha_{2} \frac{P P E_{i t}}{A_{i t-1}}+\varepsilon_{i t} \\
T A=N D A+D A
\end{gathered}
$$

Where:

$T A_{i t} \quad$ the sum of total accruals in year $t$;

$A_{\text {it-1 }}$ the sum of assets in year $t-1$;

$\triangle R E V_{i t}$ the change in revenues between years $t$ and $t-1$;

$\triangle R E C_{i t}$ the change in receivables between yearst and $t-1$;

$P P E_{i t}$ the sum of the property, plant \& equipment in year $t$;

$\varepsilon_{i t} \quad$ statistical error;

NDA non-discretionary accruals;

$D A \quad$ discretionary accruals. 
DA calculated by the modified Jones model are also known as abnormal accruals. These accruals are used as an estimation of the EM initiatives. The higher the absolute value of DA is, the lower is the quality of reported achieved earnings.

\subsection{Hypothesis Development}

The hypothesis was derived from the research question: Is there a difference in the level of earnings management regarding to the level of EVA indicator?

To verified hypothesis, the one-way ANOVA test was used.

$$
\begin{gathered}
S S T=S S B+S S E \\
\sum_{i=1}^{n}\left(x_{i}-\bar{x}\right)^{2}=\sum_{j=1}^{k}\left(\bar{x}_{J}-\bar{x}\right)^{2} n_{j}+\sum_{i=1}^{n_{j}} \sum_{j=1}^{k}\left(x_{i}-\bar{x}_{J}\right)^{2}
\end{gathered}
$$

Where:

$\begin{array}{ll}x_{i} & \text { i-th value of interval variable; } \\ n & \text { sample size; } \\ \bar{x} & \text { mean; } \\ n_{j} & \text { the frequency of the } \mathrm{j} \text {-th group; } \\ k & \text { the number of nominal variable groups; } \\ \overline{x_{j}} & \text { mean } \mathrm{j} \text {-th group. }\end{array}$

The estimate of intergroup (MSB) and intragroup (MSE) variance can then be expressed as the ratio between the sum of squares and the corresponding number of degrees of freedom.

$$
\begin{aligned}
& M S B=\frac{S S B}{k-1} \\
& M S E=\frac{S S E}{n-k}
\end{aligned}
$$

Possible decision criterion is based on the achieved $p$-value, which we compare with the chosen level of significance. This was determined by using statistical analysis software in Excel XLSTAT. If the $p$-value at the selected significance level $\alpha=0.05$ is less than 0.05 , this means that the differences in the sample averages are too large to be random, we reject $\mathrm{H} 0$ and do not reject Ha, which state of the existence of a statistically significant difference in the level of earnings management regarding to the level of EVA indicator.

\section{Results, Discussion and Conclusions}

The results of EVA calculation are as follow. Median EVA in 2015 was 59,259 EUR. Compared to the other observed years, it is the lowest value. Median EVA in 2016 was 79,826 EUR, in 2017 it was 88,563 EUR. The highest value was calculated in 2018 - 104,519 EUR. In 2019 median EVA decreased by 5, 793 EUR. Median EVA in 2019 was 98, 726 EUR. The upper and the lower quartile were calculated. The results can be seen in Table 1 . 
Table 1. The upper and the lower quartile of EBIT DA

\begin{tabular}{ccc}
\hline Year & The Upper Quartile & The Lower Quartile \\
\hline 2015 & 348,618 & 21,616 \\
2016 & 355,967 & 24,193 \\
2017 & 311,606 & 16,293 \\
2018 & 282,151 & 14,781 \\
2019 & 232,778 & 9,348 \\
\hline
\end{tabular}

Based on the results, 3 out of 4 companies have the value of EVA maximum of 348,618 EUR or less in 2019. 25\% companies have the value of EVA maximum 21,616 EUR or less in the same year.

In the next step, the level of earnings management was estimated based on the modified Jones model described above (see Table 2).

Table 2. A preview of the calculated variable

\begin{tabular}{ccccc}
\hline \multirow{2}{*}{ Company } & \multicolumn{5}{c}{ Variables } \\
\cline { 2 - 5 } & $\frac{T A_{i t}}{A_{\text {it }-1}}$ & $\frac{1}{A_{\text {it }-1}}$ & $\frac{\Delta R E V_{i t}-\Delta R E C_{i t}}{A_{i t-1}}$ & $\frac{P P E_{i t}}{A_{i t-1}}$ \\
\hline Company 1 & 0.011997 & $8.38 \mathrm{E}-06$ & 0.216569 & 0.532105 \\
Company 2 & 0.069309 & $2.96 \mathrm{E}-05$ & 0.12202 & 0.020171 \\
Company 3 & 0.065585 & $1.83 \mathrm{E}-05$ & 0.146792 & 0.019156 \\
Company 4 & -0.03155 & $6.41 \mathrm{E}-06$ & 0.039437 & 0.821519 \\
FamaSvabovaCompany & $\ldots$ & $\ldots$ & $\ldots$ & $\ldots$ \\
\hline
\end{tabular}

The modified Jones model calculate the discretionary accruals as residuals from a regression of total accruals. The results of regression can be seen in Tables 3, 4, and 5 .

Table 3. Regression statistics

\begin{tabular}{cc}
\hline Multiple R & 0.410 \\
R Square & 0.125 \\
Adjusted R Square & 0.099 \\
Standard Error & 0.103 \\
Observations & 15,295 \\
\hline
\end{tabular}

Table 4. Regression results

\begin{tabular}{ccccccc}
\hline & Coefficients & Standard Error & t Stat & P-value & $\begin{array}{c}\text { Lower } \\
95 \%\end{array}$ & $\begin{array}{c}\text { Upper } \\
95 \%\end{array}$ \\
\hline Intercept & 0.029971 & 0.007707 & 3.484285 & 0 & 0.015413 & 0.044528 \\
$\frac{1}{A_{\text {it }-1}}$ & -234.4 & 49.33401 & -4.06828 & 0 & -331.17 & -137.631 \\
$\frac{\Delta R E V_{i t}-\Delta R E C_{i t}}{A_{i t-1}}$ & -0.03168 & 0.007707 & -3.5879 & 0 & -0.0471 & -0.01713 \\
$\frac{P P E_{i t}}{A_{i t-1}}$ & -0.14386 & 0.011988 & -10.16 & 0 & -0.16783 & -0.11988 \\
\hline
\end{tabular}


Table 5. A preview of Residuals

\begin{tabular}{ccc}
\hline Observation & Predicted Y & Residuals \\
\hline Company 1 & 0.02639 & -0.41696 \\
Company 2 & -0.06334 & -0.31404 \\
Company 3 & 0.047502 & 0.163618 \\
Company 4 & -0.01056 & -0.11084 \\
Company ... & $\ldots$ & $\ldots$ \\
\hline
\end{tabular}

In the final step, following hypothesis was tested.

H0 There is not statistically significant relationship between the level of earnings management determined by the modified Jones model and the level of EVA indicator.

$\mathrm{Ha} \quad$ There is statistically significant relationship between the level of earnings management determined by the modified Jones model and the level of EVA indicator.

The results of ANOVA test state that the differences in the sample averages are too large to be random, we reject $\mathrm{HO}$ and do not reject $\mathrm{Ha}$, which state of the existence of a statistically significant difference in the level of earnings management regarding to firm size.

\subsection{Discussion}

Literature review shows the importance of the earnings management and its implications. Reported financial indicators can be influenced by the using of the earnings management practices. The aim of the contribution was to test the hypothesis about the existence of the relationship between EVA indicator and the level of the earnings management practices using within companies.

Based on the results, there is a statistically significant relationship between EVA indicator and the level of the earnings management practices. Companies with higher value of EVA indicator use the earnings management practices to decrease reported profit. The reason can be the effort to report a low basis for calculating income tax. On the other hand, companies with lower value of EVA indicator use the earnings management practices to increase reported profit, probably in order to report a satisfactory level of profit for shareholders. We encounter this phenomenon especially in joint-stock companies.

\section{Acknowledgments}

This paper was financially supported by the Slovak Research and Development Agency - Grant NO. APVV-17-0546 Variant Comprehensive Model of Earnings Management in Conditions of The Slovak Republic as an Essential Instrument of Market Uncertainty Reduction.

\section{References}

Ayu, M., Gamayuni, R. R., \& Urbański, M. (2020). The impact of environmental and social costs disclosure on financial performance mediating by earning management. Polish Journal of Management Studies, 21(1), 74-86. https://doi.org/10.17512/pjms.2020.21.2.06

Ball, R. (1972). Changes in accounting techniques and stock prices. Journal of Accounting Research, 10, 1-41. https://doi.org/10.2307/2489860

Beneish, M. D. (2001). Earnings management: a perspective. Managerial Finance. https://doi.org/10.1108/03074350110767411 
Connolly-Barker, M., Gregova, E., Dengov, V. V., \& Podhorska, I. (2020). Internet of Things Sensing Networks, Deep Learning-enabled Smart Process Planning, and Big Data-driven Innovation in Cyber-Physical System-based Manufacturing. Economics, Management, and Financial Markets, 15(2), 23-29. https://doi.org/10.22381/EMFM15220203

Fama, E. F. (1970). Efficient capital markets: a review of theory and empirical work. The Journal of Finance, 25, 383-417. https://doi.org/10.2307/2325486

Grofcikova, J. (2020). Impact of selected determinants of corporate governance on financial performance

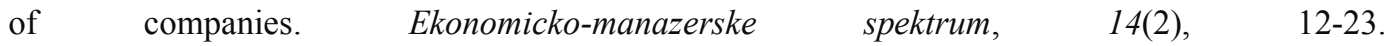
https://doi.org/10.26552/ems.2020.2.12-23

Kaplan, R. S., \& Roll, R. (1972). Investor evaluation of accounting information - some empirical evidence. Journal of Business, 45(2), 225-257. https://doi.org/10.1086/295446

Khan, K. A., Dankiewicz, R., Kliuchnikava, Y., \& Olah, J. (2020). How do entrepreneurs feel bankruptcy? International Journal of Entrepreneurial Knowledge, 8(1), 89-101. https://doi.org/10.37335/ijek.v8i1.103

Kliestik, T., Valaskova, K., Lazaroiu, G., Kovacova, M., \& Vrbka, J. (2020). Remaining Financially Healthy and Competitive: The Role of Financial Predictors. Journal of Competitiveness, 12(1), 74.

Mayer-Sommer, A. P. (1979). Understanding and acceptance of the efficient markets hypothesis and its accounting implications. Accounting Review, 54(1), 88-106.

Rath, S., \& Sun, L. (2008). The development of earnings management research. International Review of Business Research Papers, 4(2), 265-277.

Schipper, K. (1989). Earnings Management. Accounting Horizon, 3(4), 91-102.

Svabova, L., Kramarova, K., \& Durica, M. (2018). Prediction model of firm's financial distress. Ekonomicko-manazerske spektrum, 12(1), 16-29. https://doi.org/10.26552/ems.2018.1.16-29

Svabova, L., Kramarova, K., Chutka, J., \& Strakova, L. (2020). Detecting earnings manipulation and fraudulent financial reporting in Slovakia. Oeconomia Copernicana, 11(3), 485-508. https://doi.org/10.24136/oc.2020.020

Vagner, L., Valaskova, K., Durana, P., \& Lazaroiu, G. (2021). Earnings management: A bibliometric analysis. Economics and Sociology, 14(1), 249-262. https://doi.org/10.14254/2071-789X.2021/14$1 / 16$

Virglerova, Z., Conte, F., Amoah, J., \& Massaro, M. R. (2020). The Perception of Legal Risk and Its Impact on the Business of SMEs. International Journal of Entrepreneurial Knowledge, 8(2), 1-13. https://doi.org/10.37335/ijek.v8i2.115

Vrbka, J., Nica, E., \& Podhorska, I. (2019). The application of Kohonen networks for identification of leaders in the trade sector in Czechia. Equilibrium-quarterly journal of economics and economic policy, 14, 739-761. https://doi.org/10.24136/eq.2019.034

Whittle, T., Gregova, E., Podhorska, I., \& Rowland, Z. (2019). Smart Manufacturing Technologies: Datadriven Algorithms in Production Planning, Sustainable Value Creation, and Operational Performance Improvement. Economics, Management, and Financial Markets, 14, 52-57. https://doi.org/10.22381/EMFM14220193

Williams, A., Suler, P., \& Vrbka, J. (2020). Business Process Optimization, Cognitive Decision-Making Algorithms, and Artificial Intelligence Data-driven Internet of Things Systems in Sustainable Smart Manufacturing. Journal of Self-Governance and Management Economics, 8(4), 39-48. https://doi.org/10.22381/JSME8420204 